\title{
PEMBUATAN MEDIA PEMBELAJARAN BERBASIS MULTIMEDIA INTERAKTIF VISUAL MACROMEDIA FLASH SEBAGAI MODULPERKULIAHAN MOTOR LISTRIK ARUS BOLAK BALIK
}

\author{
Dimas Bagus Setioko ${ }^{1}$, Prabakti Endramawan ${ }^{2}$, Agus Hariwibowo ${ }^{3}$ \\ ${ }^{1}$ Prodi Pendidikan Teknik Elektro, FPTK, IKIP PGRI Madiun \\ Madiun, 63118, Indonesia \\ ${ }^{2}$ Prodi Pendidikan Teknik Elektro, FPTK, IKIP PGRI Madiun \\ Madiun, 63118, Indonesia \\ ${ }^{3}$ Prodi Pendidikan Teknik Elektro, FPTK, IKIP PGRI Madiun \\ Madiun, 63118, Indonesia
}

Email: dimasbspte@gmail.com

\begin{abstract}
ABSTRAK
Pembelajran dengan menggunakan media interaktif visual menggunakan animasi komputer memberikan kesempatan kepada peserta didik lebih aktif dan interaktif. Tujuan pembuatan ini menggunakan media macromedia flash player 8 adalah agar dapat memberikan kemudahan dalam penyampaian pembelajaran mata kuliah motor listrik arus bolak balik. Penelitian ini berbentuk penelitian kualitatif. Dari berbagai media pembelajaran yang berbasis multimedia visual., media menggunakan macromedia flash player 8 ini sangat diminati dan lebih menarik minat belajar. Salah satu peningkatan kualitas pembelajarn adalah dengan pemilihan strategi atau cara dalam penyampaian materi pembelajaran agar diperoleh peningkatan kompetensi belajar siswa. Salah satu cara penyampaiannya dengan menggunakan macromedia flash player 8 ini. Perkembangan teknologi juga dapat mendukung dan meningkatkan minat belajar, media pembelajaran ini dapat lebih menarik sehingga pemahaman mata kuliah motor listrik arus bolak balik lebih memahami.
\end{abstract}

Kata Kunci: Media Pembelajaran, Motor listrik arus bolak balik, Macromedia Flash player 8

\section{Pendahuluan}

Perkembangan ilmu pengetahuan dan teknologi mendorong upaya-upaya pembaharuan dalam pemanfaatan hasilhasil teknologi pendidikan dalam proses belajar mengajar. Dewasa ini bidang pengajaran secara umum sedikit banyaknya terpengaruh oleh adanya perkembangan dan penemuan-penemuan dalam bidang keterampilan, ilmu dan teknologi. Pengaruh perkembangan tersebut tampak jelas dalam upaya-upaya pembaharuan sistem pendidikan dan pembelajaran. Upaya pembaharuan itu menyentuh bukan hanya sarana fisik/fasilitas pendidikan, tetapi juga sarana nonfisik seperti pengembangan kualitas tenaga kependidikan yang memiliki pengetahuan, kemampuan, dan keterampilan memanfaatkan fasilitas yang tersedia, cara kerja inovatif, serta sikap yang positif terhadap tugas-tugas kependidikan yang diembannya.
Pembelajaran adalah proses interaksi peserta didik dengan pendidik atau pengajar dan sumber belajar pada suatu lingkungan belajar. Pembelajaran merupakan bantuan yang diberikan pendidik agar dapat terjadi proses pemerolehan ilmu dan pengetahuan, penguasaan kemahiran dan tabiat, serta pembentukan sikap dan kepercayaan pada peserta didik.

Media adalah segala sesuatu yang dapat digunakan untuk menyalurkan pesan dari pengirim ke penerima sehingga dapat merangsang pikiran, perasaan, perhatian, dan minat serta perhatian siswa sedemikian rupa sehingga proses belajar terjadi, mengemukakan stimulus visual membuahkan hasil belajar yang lebih baik untuk tugas-tugas seperti mengingat, mengenali, dan menghubung fakta dan konsep. Diharapkan dalam aktivitas belajarmengajar menggunakan media pembelajaran yang berbasis macromedia 
flash player 8 dalam penyampaian materi sehingga mudah dipahami peserta didik.

Macromedia Flash Player 8 merupakan perangkat lunak yang dapat digunakan untuk membuat sebuah animasi. Animasi adalah susunan objek yang diatur sedemikian rupa sehingga menghasilkan suatu gerakan yang mampu menarik setiap orang untuk melihatnya, agar menghasilkan animasi yang menarik yang sesuai dengan tujuan penelitian maka media pembelajaran macromedia flash player 8 harus dirancang dengan baik. Program ini dapat menampilkan informasi yang berupa tulisan, gambar, animasi, sehingga siswa/peserta didik dapat lebih tertarik dalam mengikuti pelajaran mata kuliah motor listrik arus bolak balik.

Macromedia Flash Player 8 dibuat oleh perusahaan software macromedia untuk keperluan membuat suatu aplikasi web yang interaktif dan menarik. Macromedia Flash Player 8 sering digunakan untuk membuat animasi dan untuk keperluan lain seperti membuat game dan tutorial. Aplikasi macromedia Flash Player 8 adalah aplikasi yang dapat menampilkan teks, gambar, animasi, dan audio secara bersama maka sangat mungkin apabila macromedia Flash Player 8 digunakan sebagai sarana pengembangan media pembelajaran.

Media pembelajaran sangat penting bagi Program Studi Teknik Elektro, karena setiap pembelajaran tidak hanya teori namun juga praktik. Salah satu mata kuliah yang tidak hanya teori dan membutuhkan media pembelajaran adalah mata kuliah motor listrik arus bolak balik. Kurangnya media pembelajaran pada mata kuliah motor listrik arus bolak balik di Program Studi Pendidikan Teknik Elektro, mendorong penulis untuk membuat media pembelajaran guna menambah pembelajaran agar lebih mudah penyampaian dan memahami bagi peserta didiknya.

Media merupakan alat bantu yang kita inginkan dapat memudahkan dalam melakukan sesuatu. Menurut Rusman (2013:159) media merupakan alat saluran komonikasi. Media berasal dari bahasa latin dan merupakan bentuk jamak dari kata "medium" yang secara harfiah berarti "perantara" yaitu perantara sumber pesan dengan penerima pesan. Media juga bisa diartikan pengantar pesan dari pengirim ke penerima pesan, dengan demikian media sebagai wahana penyalur informasi belajar.

Media pembelajaran memiliki peran yang penting dalam pembelajaran dan menunjang keberhasilan proses belajar mengajar. Menurut pendapat Rusman (2013:160) menyatakan bahwa media adalah komponen dalam lingkungan pembelajaran yang dapat memberikan rangsangan untuk belajar.

Media pembelajaran memiliki peran yang penting dalam pembelajaran dan menunjang keberhasilan proses belajar mengajar. Menurut pendapat Rusman (2013:160) menyatakan bahwa media adalah komponen dalam lingkungan pembelajaran yang dapat memberikan rangsangan untuk belajar.

Multimedia bisa digunakan sebagai media pendidikan yang dapat dihandalkan. Dibandingkan dengan media yang lain, multimedia mempunyai berbagai kelebihan. Multimedia mampu merangkum berbagai media seperti media teks, suara, grafik gambar, dan animasi dalam satu sajian digital.

Menurut Munir (2013:113), multimedia interaktif adalah pemanfaatan computer untuk menggabungkan teks, grafik, audio, gambar bergerak (video dan animasi) menjadi satu kesatuan dengan link tool yang tepat sehingga memungkinkan pemakai multimedia dapat melakukan navigasi, berinteraksi, berkreasi, dan berkomunikasi.

Sesuai uraian diatas, tujuan penelitian ini sebagai berikut:

1. Mengetahui alur pembuatan skema proses dasar awal hingga akhir tahapan-tahapan yang diterapkan pada media pembelajaran.

2. Mengetahui alur pembuatan dan proses awal hingga akhir tahapan -tahapan dalam menyusun modul perkuliahan mata kuliah motor listrik arus bolak balik menggunakan software aplikasi Macromedia Flash Player 8.

3. Mengetahui tahapan pembuatan agar lebih menarik, tepat, serta efektif 
sebagai media pembelajaran tambahan dengan menyampaikan materi lewat modul perkuliahan berbasis multimedia interaktif visual yang disusun lewat Macromedia Flash Player 8.

\section{Metode}

Model penelitian ini adalah kualitatif. Penelitian kualitatif adalah suatu proses yang dilakukan secara wajar dan natural sesuai dengan kondisi obyektif dilapangan tanpa ada manipulasi, serta jenis data yang dikumpulkan terutama data kualitatif.

Kajian utama penelitian kualitatif adalah fenomena atau kejadian yang berlangsung dalam situasi sosial tertentu. Peneliti harus terjun langsung ke lapangan (lokasi) untuk membaca, memahami, dan mempelajari situasi. Kegiatan peneliti adalah mengamati, mencatat, bertanya, dan menggali sumber yang erat hubungannya dengan peristiwa yang sedang terjadi saat itu.

Penelitian kualitatif lebih menekankan pada peneliti sebagai key instrument. Peneliti diharapkan mampu mengungkap fenomena yang unik dilapangan dengan mengarahkan segenap fungsi indranya.

Dalam penelitian ini penelitian kualitatif dilaksanakan pada saat proses belajar mengajar pada mata kuliah motor listrik arus bolak-balik dan mengamati penggunan media yang diberikan pengajar kepada peserta didik.

Jenis penelitian ini menggunakan penelitian grounded theory dimana Istilah grounded (diperkenalkan oleh Glaser dan Strauss). Menurut ilmuwan, metode grounded theory dikatakan sebagai metode ilmiah karena prosedur kerjanya yang dirancang secara cermat sehingga memenuhi kriteria sebagai metode ilmiah, yaitu adanya ketelitian dan ketepatan, adanya kesesuaian atau signifikansi antara teori dan observasi, dapat dibuktikan dan diteliti ulang.

Tujuan pendekatan grounded theory adalah untuk menghasilkan atau menemukan suatu teori yang berhubungan dengan situasi tertentu. Situasi di mana individu saling berhubungan, bertindak, atau terlibat dalam suatu proses sebagai respon terhadap suatu peristiwa. Inti dari pendekatan grounded theory adalah pengembangan suatu teori yang berhubungan erat kepada konteks peristiwa dipelajari.

Teknik pengumpulan data yang dilakukan untuk membahas penelitian tentang pembuatan media pembelajaran pada mata kuliah motor listrik arus bolak balik ini adalah:

1. Mempelajari buku tentang proses pembelajaran dan penggunanan media dalam pembelajaran di perpustakaan IKIP PGRI Madiun serta perpustakaan umum, dan memahami jurnal penelitian pendidikan tentang media pembelajaran sebagai acuan dalam melaksanakan penelitian.

2. Memahami rencana pelaksanaan pembelajaran pada mata kuliah motor listrik arus bolak-balik dan mempelajari kembali isi pelajaran yang akan di buat dalam media sebagai bahan dalam pembuatan media.

3. Studi lapangan dengan mengamati dan mempelajari proses pembelajaran dan penggunaan media saat proses belajar mengajar sedang berlangsung.

4. Wawancara terhadap subjek penelitan dalam hal ini adalah mahasiswa.

5. Mendokumentasikan proses belajar mengajar.

Keabsahan data diperlukan untuk mendapatkan data atau hasil penelitian yang valid, dalam hal ini pembuatan media pembelajaran berbasis macromedia flash player 8. Teknik keabsahan data yang diambil oleh peneliti adalah berdasarkan metode trianggulasi sumber pada mata kuliah/pelajaran motor listrik arus bolak balik. Trianggulasi sumber atau yang sebagai tim pakar maupun tim ahli.

\section{Hasil Penelitian dan Pembahasan}

Dalam penelitian ini peneliti memiliki temuan yaitu dalam pembuatan media pembelajaran menggunakan software macromedia flash player 8 perlu diperhatikan dan konsentrasi dalam pembuatan skema yang telah dibuat, terutama dalam memberikan link pada media pembelajran. Karena link seperti 
alamat bila salah memasukkan link maka media yang dibuat tidak bisa sesuai yang diinginkan.

Dalam memasukkan link peneliti masih menemukan beberapa masalah link yang salah dalam memberikan menu down baar pada media tersebut. Hasilnya banyak yang tidak sesuai dalam konsep peneliti, hal ini dikarenakan terlalu banyak jumlah menú down baar. Sehingga membuat model tersebut peneliti harus banyak merubah konsep yang diinginkan.

Prinsip Kerja dari media pembelajaran ini adalah pemberian link yang sesuai agar dapat berjalan dengan tahap perencanaan . Jadi fungsi link ini adalah menghubungkan antara frame satu ke frame yang lain sehingga dapat terkoneksi dengan baik. Disaat kita klik salah satu link maka secara otomatis terhubung dan terkoneksi dengan frame yang telah dihubungkan pada tahap pembuatan oleh peneliti.

\section{Kesimpulan}

Berdasarkan hasil penelitian yang dilakukan di Program Studi Pendidikan Teknik Elektro IKIP PGRI Madiun, maka dapat disimpulkan:

1. Harus menyesuaikan dengan media pembelajaran dengan Silabus dan SAP yang berlaku dan kemudahan menerima media pembelajaran tersebut.

2. Tahapan proses awal hingga akhir pembuatan media pembelajaran yaitu:

a. Tahap pembuatan layer tampilan.

b. Tahap pengisisan data (teks dan gambar).

c. Tahap pemberian link

3. Dalam perencanaan ini peneliti membuat perencanaan ini mengumpulkan beberapa data yang dibutuhkan untuk pembuatan media pembelajaran, diantaranya data tersebut yaitu Silabus, SAP, dan Materi mata kuliah. Setelah data yang terkumpul peneliti melakukan perancangan konsep dan sketsa secara manual agar bisa diterima dan dipahami. Kemudian tahap selanjutnya pembuatan media pembelajaran ini dengan menggunakan software macromedia flash player 8

Dari hasil pembuatan media pembelajaran pada mata kuliah motor listrik arus bolak balik menggunakan software macromedia flash player 8 dapat ditarik kesimpulan bahwa hasil media pembelajran ini berjalan baik dan sesuai yang diharapkan. Hal ini terlihat dari tahap pengujian yang dilakukan di depan tim ahli dan dosen pengampu, bahwa media pembelajaran yang dibuat sesuai dengan Silabus dan SAP (Satuan Acara Perkuliahan).

Selain itu media pembelajaran ini berjalan mulus dan baik tanpa ada kendala atau tanpa adanya kesalahan dalam pemberian link. Dengan demikian media pembelajaran mata kuliah motor listrik arus bolak balik menggunakan software macromedia flash player 8 siap digunakan untuk tahun ajaran 2016/ 2017.

\section{DAFTAR PUSTAKA}

Munir. 2013. Multimedia Konsep dan Aplikasi Dalam Pendidikan.

Bandung : Alfabeta

Rusman, $2013 . \quad$ Model-Model Pembelajaran. Edisi Kedua. Jakarta : PT Raja Grafinda Persada

Sanjaya, Wina. 2010. Penelitian Tindakan Kelas. Jakarta : Prenade Media

Warsita, Bambang. 2008. Teknologi Pembelajaran, Landasan dan Aplikasinya Jakarta : Rineka Cipta

Yudhiantoro, Dhani. 2006. Membuat Animasi Web dengan Macromedia Flash m Profesional 8. Yogyakarta : Andi Ofset 